\title{
WHO ARE MEMBERS OF THE CHURCH?
}

(A statement of Evidence in criticism of a Sentence in the appeal to all Christian People made by the Lambeth Conference of I920, which is fundamental to all the propositions of that appeal), by DARWELL STONE, D.D., and F. W. Puller, M.A. (Longmans, Green \& Co. 8vo., pp. 88., paper. $2 / 6$ net.)

THIS slender pamphlet is likely to be a spearpoint. It cannot be overlooked. If looked into it cannot be refuted.

It proves that the Lambeth Appeal is wrong in saying that anyone is a member of the Church who is baptized, and has belief in our Lord.

It says, "The Lambeth statement may be understood to mean first, either that the organized bodies of baptized believers who believe in our Lord and are in schism are parts of the Church; or, second, that while these bodies are outside the Church the members of them as individuals are members of the Church.

"In either case the statement is contrary to that consensus of patristic teaching of which we have given instances. For both the separated bodies as such and the individual members of them are regarded by the Fathers as outside the Church" (p. 23).

Dr. Stone and Father Puller, therefore, teach that even if a Church has a valid apostolic succession and teaches the whole Catholic faith without heresy, but is in schism, it is not part of the Church. Moreover, an adult who remains in communion with this nonheretical, but schismatical, Church is not a member of the Church!

This sound doctrine of Dr. Stone and Father Puller, if honestly accepted, would bring the quest for $\mathrm{Re}-$ union into a new phase. Dr. Stone and Father Puller apply it very effectively to those bodies who separated from the Church of England. It proves an irrefutable principle regulating the relations between the Church 


\section{Who are Members of the Church?}

of England and the Free Churches. But if valid between these, it must be valid between the Church of Rome and the Church of England.

The principle is quite clear. A Church in schism is not a member of the True Church. A member of a Church in schism is not a member of the True Church. Two churches, therefore, between which the relation is one of schism cannot both be the True Church; one of them is not part of the True Church.

But the relation between the Church of Rome and the Church of England is one of schism. Schism is the permanent refusal to submit to jurisdictional authority. Now the Church of Rome refuses to submit to the jurisdictional authority of the Church of England. The Church of England refuses to submit to the jurisdictional authority of the Church of Rome. Moreover, the Church of Rome (if not the Church of England) refuses to submit to any third visible Church. Neither Church submits to a common visible Church. Therefore, if either the Church of Rome or the Church of England is in schism, either the Church of Rome or the Church of England is not part of the True Church. We therefore ask Dr. Stone and Father Puller and their fellow Anglo-Catholics, "Which Church is in schism? Rome or England ?"

We leave this conclusion from Dr. Stone and Father Puller's book in this half-way position. In the name of the Spirit of Truth and Unity we ask for a plain answer to our poignant question.

Fr. Vincent McNabb, O.P. 